\title{
薄板スポット溶接部の非破壊評価技術*1
}

\author{
高田 $-1, * 2$ 尾関孝文 ${ }^{1} \quad$ 池田倫 正 $^{1} \quad$ 広 瀬 智 行 $^{2}$ \\ ${ }^{1} \mathrm{JFE}$ スチール株式会社スチール研究所 \\ ${ }^{2} \mathrm{JFE}$ スチール株式会社西日本製鉄所
}

J. Japan Inst. Metals, Vol. 76, No. 9 (2012), pp. 555-562

(C) 2012 The Japan Institute of Metals

\section{Ultrasonic Method for Testing Spot-Welds}

\author{
Hajime Takada ${ }^{1, * 2}$, Takahumi Ozeki ${ }^{1}$, Rinsei Ikeda ${ }^{1}$ and Tomoyuki Hirose ${ }^{2}$ \\ ${ }^{1}$ Steel Research Laboratory, JFE Steel Corporation, Kawasaki 210-0855 \\ ${ }^{2}$ West Japan Works, JFE Steel Corporation, Fukuyama 721-8510
}

\begin{abstract}
We developed a technique for nondestructively evaluating spot-welds based on through-transmission of Lamb waves. The nugget diameter can be evaluated by measuring the width of the zone where attenuated transmitted waves are observed. A particularly important feature of the developed technique is that spot-welds with no weld metal can be reliably distinguished from spot-welds with weld metal. We also developed a measuring system using array transducers. The measurement results using the system agree well with the nugget diameters measured by cross-sectional observation.
\end{abstract}

(Received January 30, 2012; Accepted June 20, 2012; Published September 1, 2012)

Keywords: spot welds, nondestructive testing, ultrasound, probe array, nugget diameter

\section{1. 緒言}

自動車や家電製品の製造では, 製品を構成する部材は多数 の点でのスポット溶接により組み立てられる. スポット溶接 は, 通常, $2 \sim 4$ 枚の重ねた薄鋼板を, 数 $\mathrm{mm}$ の径の電極チ ップに挟み加圧して行われる. スポット溶接部を外からみる と，小さな凹みに見えることが多い.

このスポット溶接部の健全性は, 溶接された物体の強度や 耐久性に直接影響するため, 注意深く検査される必要があ る. スポット溶接部を検査する従来法の 1 つとして, 溶接 金属の断面をチェックする方法がある.もう 1 つの方法と して, 積層された板の境界へタガネを差し込んで剥離の有無 や剥離しない部分の大きさを確認する方法(タガネ試験)が採 用されている。しかし，これらの方法には，破壊的である （スポット溶接部を壊す）こと，抢よび製品からサンプリング されたスポット溶接部しか評価できないことの問題があっ た。このため, 産業界は永くスポット溶接部の信頼性が高い 非破壊検査方法を待ち望んできた.

過去にスポット溶接部の非破壊評価を志向して垂直多重工 コー減衰法に基づく超音波試験方法 ${ }^{1-6)}$ や電磁気的な方法が 開発されてきた。しかし, 従来の超音波試験方法には, スポ ット溶接部の形状の影響を受けやすい問題や十分に溶接金属 が生成された溶接部と溶接金属がほとんど生成されていない

*1 Mater. Trans. 52(2011) 539-546 に揭載

*2 現在 : JFE テクノリサーチ秼 (Present address: JFE TechnoResearch Corporation)
溶接部とを識別できない致命的な問題があった.

また, 溶接部に打ける透磁率や導電率の測定值に基づきス ポット溶接部の良否判定を行う電磁気的方法も, 測定結果が 溶接部の形状によって強く影響をうけるため, 不完全なもの であった．特に，溶接金属がないスポット溶接部と溶接金属 があるスポット溶接部とを識別できる信頼性がある評価手段 はなく, 超音波法も電磁気法もスポット溶接部非破壊試験に 対して信頼性がなかった。 また, 最近 10 年の間に垂直法を 用いた超音波映像化技術がスポット溶接部非破壊試験に適用 されてきた7-10). しかし，それら技術も上記した垂直多重工 コー減衰法と同様の問題点をなだ有している.

そこで, 著者らは, 最近, スポット溶接部の非破壊評価試 験において溶接金属があるスポット溶接部と溶接金属がない スポット溶接部とを識別できる万法(以下，開発法)を開発し た.この論文ではこの新しい方法の概要を示す.

\section{2. 従来のスポット溶接部非破壊試験方法の問題点と 開発法の原理}

\section{1 従来法の問題点}

Fig. 1 はスポット溶接部断面の光学顕微鏡像の例を示す. Fig. 1 (a) は溶接金属が生成されていないスポット溶接部の 断面を示し，Fig. 1(b)は十分な大きさの溶接金属が生成さ れているスポット溶接部の断面を示している。（b)において 溶接金属は厚さ方向に指向した組織を有している，その理由 は，スポット溶接により生成された熱が電極に向かい移動 し, 温度勾配が厚さ方向に発生するからである. 
(a) Spot-weld with no weld metal

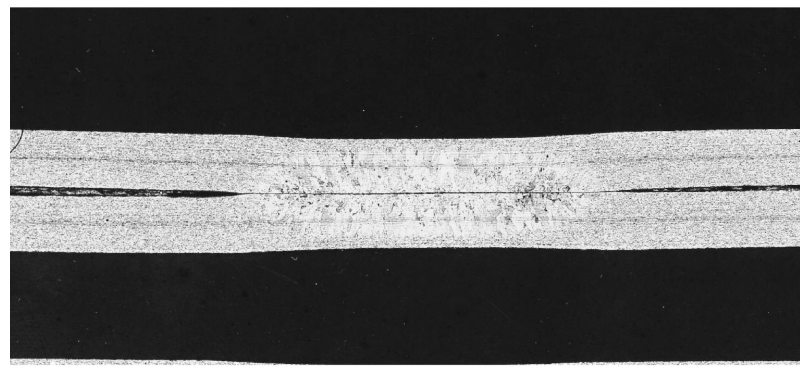

(b) Spot-weld with weld metal

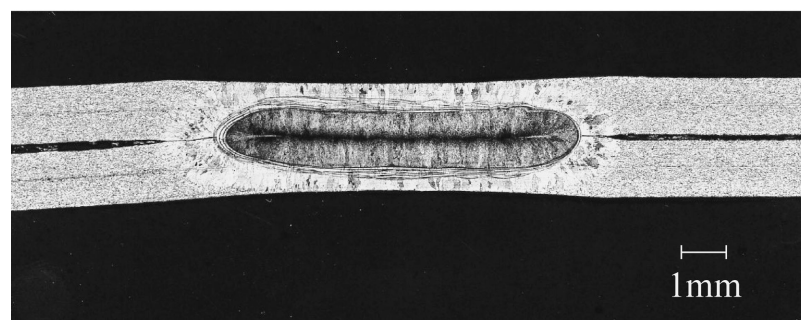

Fig. 1 Optical micrograph of typical weld metal.

緒言において紹介した垂直多重エコー減衰法に基づく超音 波試験方法 ${ }^{1-6)}$ においては, Fig. 2(a)に示すようにスポット 溶接部の直上に垂直超音波探触子を接触媒質を介して押し当 て，鋼板の厚さ方向に超音波を送波し，反射波を受波する. 垂直超音波探触子の前面には，スポット溶接部の凹みのある 形状に超音波放射面の形状を合わせるため, 液体が入ったゴ ム膜が取り付けられている.

Fig. 2(b) に示す線図は溶接金属の生成状態と垂直多重工 コー減衰法を用いて計測される超音波透過度 (Transmissivity，見かけの超音波減衰とは反比例）との関係を示してい る.（b）において溶接金属がない(No weld metal)として示 されている領域 I (Stage I ) におけるスポット溶接部の状態 は，溶接金属が生成されず，2枚の鋼板の界面が融着してい るだけの状態であり (Fig. 1(a)参照), Fig. 2(b)の横軸右側 へ向かって融着部の面積が増大する.この領域では融着部の 面積増大に伴い，界面に打ける超音波透過度が増大するの で，見かけ上，超音波減衰が低下していくように見える。こ のような溶接金属なしのスポット溶接部が生成される原因と して, 溶接電流の不足, 通電時間の不足, およびスポット溶 接用電極チップの損耗などが挙げられる，また，溶接金属が ないスポット溶接部はごくわずかな量の金属の融着で形態を 保っているだけであるので，機械的強度がきわめて低く，製 品強度を低下させるため, 非破壊検査によって排除されるべ き不具合である。（b）に打ける領域Ｉ（Stage II）に打いて は，横軸右側に向かって生成される溶接金属の大きさが増大 することを意味している．溶接金属の結晶組織は一般に母材 の結晶組織と比べて粗いため, 超音波減衰が大きくなる.よ って, 溶接金属の大きさが増大して溶接金属の厚さも大きく なる横軸右側ほど超音波減衰は大きくなり，超音波透過度が 低下する．このようなことから，（b）に示した溶接金属の生 成状態と垂直多重エコー減衰法を用いて計測される超音波透 過度との関係は逆 U 字型になり，溶接金属(ナゲット)の異 なる生成状態において同じ測定值が得られる可能性がある. (a) Conventional ultrasonic testing technique Ultrasonic probe

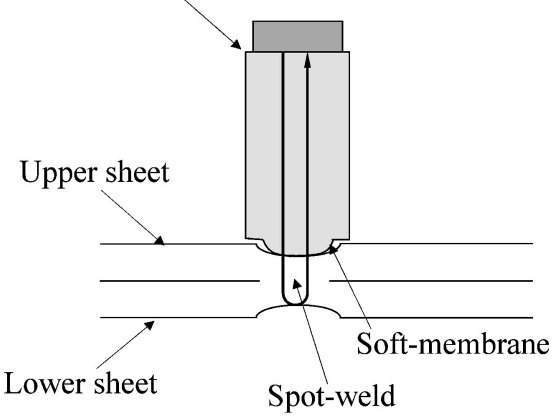

(b) Estimated transmissivity as the function of the growth of weld metal

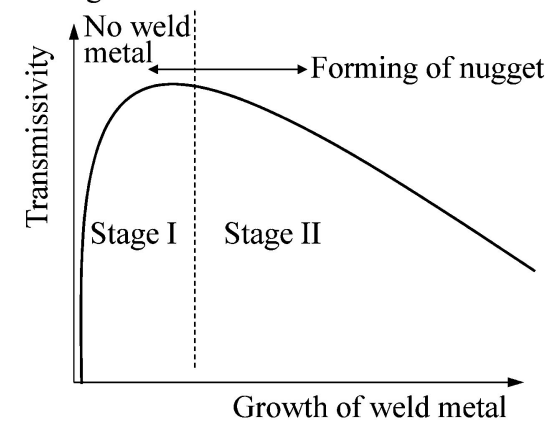

Fig. 2 Spot-weld evaluation method using (a) the conventional ultrasonic decay technique and (b) estimated transmissivity as the function of the growth of weld metal with the method.

より詳細には, 溶接金属がないスポット溶接部において観察 される超音波透過度，あるいは，減衰が，大きな溶接金属が あるスポット溶接部で観察される超音波透過度，あるいは， 減衰と等しくなる可能性がある.すなわち，この方法によっ ては上記した 2 つの異なる溶接金属生成状態を識別するこ とができない。

また，Fig. 1 に示した断面写真では比較的軽微であるもの の電極チップによる加圧によってスポット溶接部の電極チッ プ当接部は凹んだ形状となるのが一般的である。凹んだ部分 の端部では溶接部表面に斜めの面が形成される．この斜めに なった表面の下の部分を垂直法に基づくこの方法では評価で きない，その理由は，送波された超音波が斜め面で散乱され るからである。

\section{2 開発法の原理}

\subsection{1 水平方向超音波減衰測定}

開発法で使用している板波には $\mathrm{A}_{n}$ モード $(n=0,1,2$, $\cdots$, 以下 $\mathrm{A}$ モード $), \mathrm{S}_{n}$ モード $(n=0,1,2, \cdots$, 以下 $\mathrm{S}$ モ一 ド)の伝搬モードがある. 板波の周波数を $f$ ，板波が伝搬す る媒体の厚さを $d$ としたとき，ふつう， $\mathrm{A}$ モード抢よび $\mathrm{S}$ モードは振動様式が同じであれば, $f \cdot d$ 值の変化によって モードを区別することはないが，説明の簡素化のため，以下 の説明に抢いては，異なる $f \cdot d$ 值をもつ板波を，伝搬モ一 ドの同一，あるいは，相違に関係なく，別のモードであると して説明する，ただし，紛らわしさを避けるため，モードと 斜体で記述する.

Fig. 3 は著者らが最近開発したスポット溶接部非破壊試験 
(a) Spot-weld with no weld metal

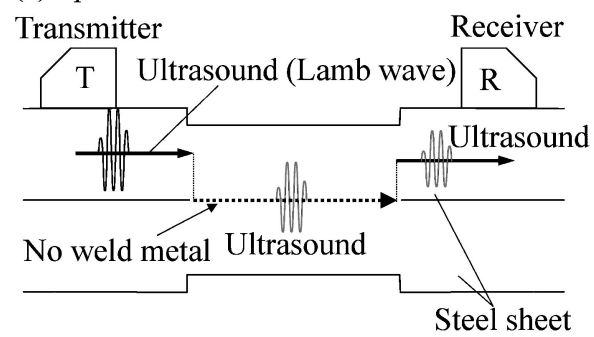

(b) Spot-weld with weld metal

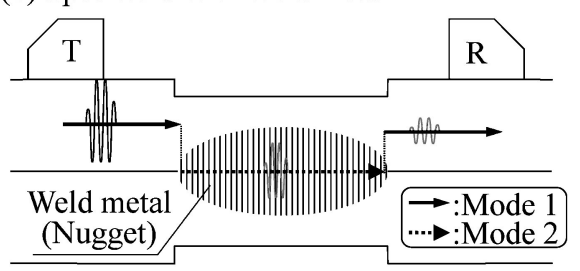

(c) Estimated transmissivity as the function of the growth of weld metal

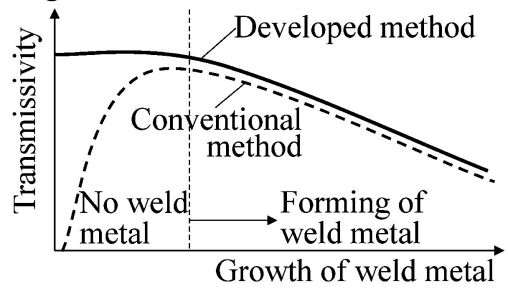

Fig. 3 Spot-weld evaluation method using the difference between (a) ultrasound (Lamb wave) propagation in the spotweld with no weld metal and (b) that in the spot-weld with weld metal; and (c) estimated transmissivity as the function of the growth of weld metal.

方法の概要を示している. 超音波(板波)がスポット溶接部の 溶接金属(ナゲット)外側の「送波点」から送波され，その波 はある伝搬モード（板波のモード，ここではモードを特定し ないのでモード 1 と仮称）として溶接金属へ向かい伝搬す る．超音波が溶接金属の端に到達すると，厚さ变化のために $f \cdot d$ 值が変化するので，板波の伝搬モードは他のモードへ 変換され（ここではモードを特定しないのでモード 2 と仮 称），さらに超音波は伝搬モード 2 として溶接金属の他方の 端へ向かい伝搬する．溶接金属の他方の端において，板波の 伝搬モードは元のモード（モード 1)へ変換され（Fig. 1 に示 したように, 溶接部の断面形状は一般に溶接部中心に対して ほぼ左右対称であるので，総体として板波を形成する縦波お よび横波の個々の伝搬方向も溶接部中心に対してほぼ左右対 称になるため, 溶接金属を透過した波は元のモード 1 へ戻 る.)，さらに板波は送波点の向かいにある「受波点」へ向か い伝搬する. 最終的に透過波が受波点に打いて検出される.

溶接金属は溶接される鋼板の結晶組織と比較して粗い組織 をもっているので, 溶接金属に到達してモード 2 にて伝搬 する板波は，伝搬するにつれて減衰して徐々に振幅が小さく なり，溶接金属他端では小さな振幅の波となる.よって，こ れが変換されたモード1の板波の振幅も小さくなる．この 結果, Fig. 3(b) に模式的に示すように低い水平方向超音波 透過度 (大きな水平方向減衰) が観察される．対照的にスポッ 卜溶接部に溶接金属がなければ，伝搬路程に粗い組織が存在 しないため，溶接金属に到達してモード 2 にて伝搬する板
波は，粗い結晶組織での減衰を受けることなく伝搬し，これ が溶接金属他端で変換されたモード 1 の板波の振幅は大き なものとなる．この結果，Fig. 3(a)に示すように超音波の 高い水平方向透過度 (小さな水平方向減衰)が観察される. 2 枚の鋼板が接合されていない場合には，(a)に示されている のと同様な振幅の大きな透過波が観察される．Fig. 3(c) は 超音波透過度の推定值と溶接金属の生成状態との関係を示し ている. 開発法に打ける水平方向超音波透過度推定值は溶接 金属生成状態の単調減少関数になる。したがって，透過波の 振幅を観察することにより溶接金属があるスポット溶接部と 溶接金属がないスポット溶接部との識別を容易に実行でき る.これに対し，垂直法に基づいた従来法での超音波透過度 は異なる溶接金属の生成状態において同じ值となる。よっ て，従来法を用いることにより溶接金属があるスポット溶接 部と溶接金属がないスポット溶接部との識別を行うことは容 易でない。

鋼板の表面沿いに伝搬する超音波は，溶接金属中での伝搬 路程，すなわち，ナゲット径に比例して減衰される。よっ て，水平方向での超音波減衰を測定することによりナゲット 径を測定可能である. しかし, 超音波減衰測定の正確さは超 音波プローブと試験体との音響結合に依存する．よって，ナ ゲットによる水平方向減衰が観察される平面領域の大きさを 検出することによりナゲット径を評価する試験方法の方が，

信頼性が高くなる.

水平方向での超音波減衰はスポット溶接部に形成されるス テップ状の形状(段差)による超音波の散乱によって変わりう る.しかし，超音波は鋼板に沿って数多くのモードで伝搬す る.このようなことから，ステップ状の形状の影響を最小に する伝搬モードを用いることが可能である.

\section{2 .2 水平方向超音波透過時間測定}

スポット溶接部溶接金属の厚さ方向に指向した組織は，ま た，水平等方性弾性体と同様な異方性を有している．異方性 がある媒体では伝搬方向に依存して超音波速度が変化するの で，溶接金属が存在する領域を水平方向透過時間測定によっ ても識別できる，異方性媒体に対する一般的な構成方程式は 以下の式により与えられる11,12)。記載していない要素の值は 0 である。

$$
\left(\begin{array}{c}
\tau_{x x} \\
\tau_{y y} \\
\tau_{z z} \\
\tau_{y z} \\
\tau_{z x} \\
\tau_{x y}
\end{array}\right)=\left(\begin{array}{llllll}
C_{11} & C_{12} & C_{13} & & & \\
C_{21} & C_{22} & C_{23} & & & \\
C_{31} & C_{32} & C_{33} & & & \\
& & & C_{44} & & \\
& & & & C_{55} & \\
& & & & & C_{66}
\end{array}\right)\left(\begin{array}{c}
e_{x x} \\
e_{y y} \\
e_{z z} \\
e_{y z} \\
e_{z x} \\
e_{x y}
\end{array}\right)
$$

ここで $\tau_{i j}$ は応力テンソル,$e_{i j}$ は歪テンソル, $C_{i j}$ は弾性ステ ィフネス定数行列である. 水平等方性弾性体の対称性を考慮 すると, 式( 1 )は下記のように単純化される13).

$$
\left(\begin{array}{c}
\tau_{x x} \\
\tau_{y y} \\
\tau_{z z} \\
\tau_{y z} \\
\tau_{z x} \\
\tau_{x y}
\end{array}\right)=\left(\begin{array}{llllll}
C_{11} & C_{12} & C_{13} & & & \\
C_{12} & C_{11} & C_{13} & & & \\
C_{13} & C_{13} & C_{33} & & & \\
& & & C_{44} & & \\
& & & & C_{44} & \\
& & & & & C_{66}
\end{array}\right)\left(\begin{array}{c}
e_{x x} \\
e_{y y} \\
e_{z z} \\
e_{y z} \\
e_{z x} \\
e_{x y}
\end{array}\right)
$$


ここで, $C_{66}=\left(C_{11}-C_{12}\right) / 2 ; z$ 方向は溶接金属の厚さ方向で ある。運動方程式は下式で与えられる。

$$
\begin{aligned}
& \rho \cdot \frac{\partial^{2} u}{\partial t^{2}}=\frac{\partial x x}{\partial x}+\frac{\partial x y}{\partial y}+\frac{\partial x z}{\partial z}, \\
& \rho \cdot \frac{\partial^{2} v}{\partial t^{2}}=\frac{\partial y x}{\partial x}+\frac{\partial y y}{\partial y}+\frac{\partial y z}{\partial z}, \\
& \rho \cdot \frac{\partial^{2} w}{\partial t^{2}}=\frac{\partial z x}{\partial x}+\frac{\partial z y}{\partial y}+\frac{\partial z z}{\partial z}
\end{aligned}
$$

ここで $(u, v, w)$ は変位， $\rho$ は密度である．超音波の伝搬は上 述した $2 つ の$ 等式を満足する。ここで，一般的な解として 以下の平面波を仮定する.

$$
\begin{aligned}
& u=A_{x} \cdot \exp (2 \pi i(k \cdot D L-V \cdot t) / \lambda), \\
& v=A_{y} \cdot \exp (2 \pi i(k \cdot D L-V \cdot t) / \lambda), \\
& w=A_{z} \cdot \exp (2 \pi i(k \cdot D L-V \cdot t) / \lambda)
\end{aligned}
$$

ここで， $k=(l, m, n) ; D L=(x, y, z), V$ は超音波速度， $\lambda$ は 波長である。よって，式 $(1) \sim(3)$ から次の等式が得られ る。

$$
\left|\begin{array}{ccc}
A_{1}-\rho \cdot V^{2} & \alpha & \beta \\
\alpha & A_{2}-\rho \cdot V^{2} & \gamma \\
\beta & \gamma & A_{3}-\rho \cdot V^{2}
\end{array}\right|\left|\begin{array}{c}
A_{x} \\
A_{y} \\
A_{z}
\end{array}\right|=0
$$

ここに

$$
\begin{aligned}
& A_{1}=C_{11} \cdot l^{2}+\left\{\left(C_{11}-C_{12}\right) / 2\right\} \cdot m^{2}+C_{44} \cdot n^{2}, \\
& A_{2}=\left\{\left(C_{11}-C_{12}\right) / 2\right\} \cdot l^{2}+C_{11} \cdot m^{2}+C_{44} \cdot n^{2}, \\
& A_{3}=C_{44} \cdot l^{2}+C_{44} \cdot m^{2}+C_{33} \cdot n^{2}, \\
& \alpha=\left(C_{13}+C_{44}\right) \cdot m \cdot n, \\
& \beta=\left(C_{13}+C_{44}\right) \cdot n \cdot l, \\
& \gamma=\left\{C_{12}+\left(C_{11}-C_{12}\right) / 2\right\} \cdot l \cdot m
\end{aligned}
$$

自明でない解を得るためには左辺の行列式が 0 であるこ とが必要であるので, 超音波速度と弾性スティフネス定数と の関係が決定される. 次に弾性スティフネス定数の值を特定 の方向へ伝搬する超音波の速度を測定することにより得るこ とができる，この結果，任意の方向へ伝搬する超音波の速度 を弾性スティフネス定数の值に基づき計算することができる.

極低炭素鋳鋼を水平等方性鋼の代表的サンプルとして用 い，一方向に指向した凝固組織について測定した弾性スティ フネス定数を Table 1 に示す. Fig. 4 は Table 1 の值を用い て計算した超音波速度曲面である。両方の横波速度 $V_{\mathrm{SV}}$, $V_{\mathrm{SH}}$ および縦波速度 $V_{\mathrm{L}}$ は伝搬方向に依存して変化している.

以上で示したサンプルは低炭素鋼の溶接金属に対する結果 ではない。しかし，速度曲面の形状は溶接金属においても同 様であると考えられる，よって，溶接金属を通過した超音波 を水平方向透過時間測定からも識別できる，溶接金属が存在 する領域も水平方向透過時間測定から識別可能である。

Table 1 Elastic constant stiffness coefficients.

\begin{tabular}{cc}
\hline Elastic constant stiffness coefficients $/ \rho$ & Measured value \\
\hline$\left(C_{11} / \rho\right) /\left(\mathrm{m}^{2} / \mathrm{s}^{2}\right)$ & $3.37 \times 10^{7}$ \\
\hline$\left(C_{33} / \rho\right) /\left(\mathrm{m}^{2} / \mathrm{s}^{2}\right)$ & $3.21 \times 10^{7}$ \\
\hline$\left(C_{44} / \rho\right) /\left(\mathrm{m}^{2} / \mathrm{s}^{2}\right)$ & $1.53 \times 10^{7}$ \\
\hline$\left(C_{12} / \rho\right) /\left(\mathrm{m}^{2} / \mathrm{s}^{2}\right)$ & $1.75 \times 10^{7}$ \\
\hline$\left(C_{13} / \rho\right) /\left(\mathrm{m}^{2} / \mathrm{s}^{2}\right)$ & $1.47 \times 10^{7}$ \\
\hline
\end{tabular}

\section{3. 振動子アレイを用いたスポット溶接部評価方法お よび開発した測定システム}

2.2.1において述べたように，超音波減衰測定の精度は超 音波探触子と被検体との音響結合状態に依存する。そこで， ナゲットによる水平方向超音波減衰が観察される部位の平面 的な広がりを検出することによりナゲット径を評価する試験 方法を研究することとした。しかし，製造現場におけるスポ ット溶接部非破壊評価には探触子対の機械走査は適切ではな い，代わりに，振動子アレイを用いて超音波ビームを直線走 査する方法を開発した.

\section{1 振動子アレイを用いた測定システム}

開発した測定装置の外観を Fig. 5 に示す. 1 台の超音波送 受波器とアレイ探触子(振動子アレイ)との間にスイッチング 回路を介在させ，超音波送受波器とアレイ探触子の圧電素子 との接続を变更する．受波された透過波の信号はすべて A/ $\mathrm{D}$ 変換されてパソコン $(\mathrm{PC})$ で処理される. パソコン上で動 作する信号処理アプリケーションソフトにより水平方向透過 波(以下，単に透過波)の振幅および透過時間が検出され表示 される．すべての構成部品がプラスチックケースにまとめら

\section{(a) Longitudinal Wave}

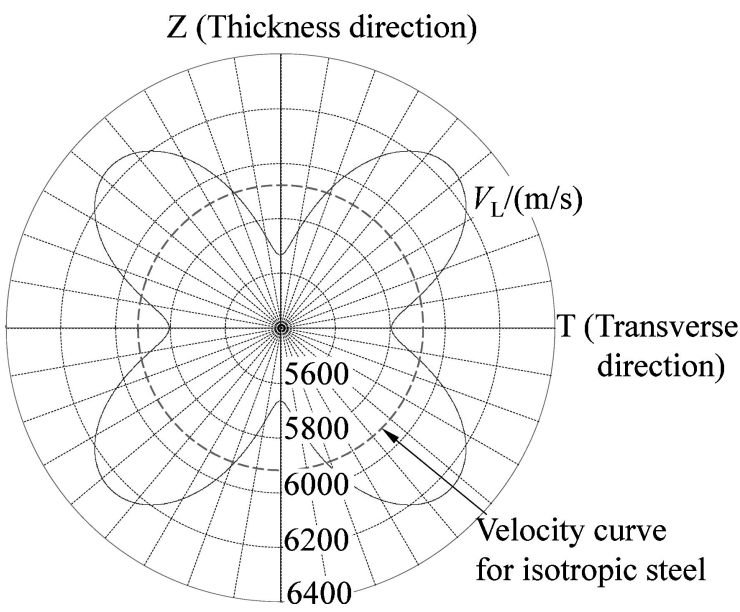

(b) Shear Wave $\mathrm{Z}$ (Thickness direction)

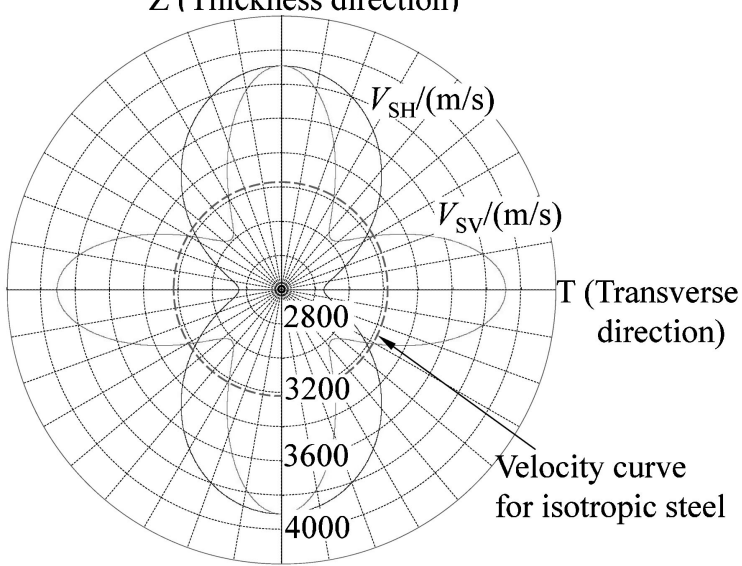

Fig. 4 Velocity curve of (a) longitudinal wave and (b) shear wave in thickness-direction-oriented structure. 
れているので，測定システムは取り扱いが容易であり，必要 とされる所どこへでも持ち出すことが可能である.

Fig. 6 は開発した振動子アレイ(アレイ探触子)を用いた測 定の模式図と対になった振動子アレイの外観を示している. 送波用探触子も受波用探触子も広帯域パルスを送受波可能な 振動子アレイを備えている. 各振動子アレイは周波数 10

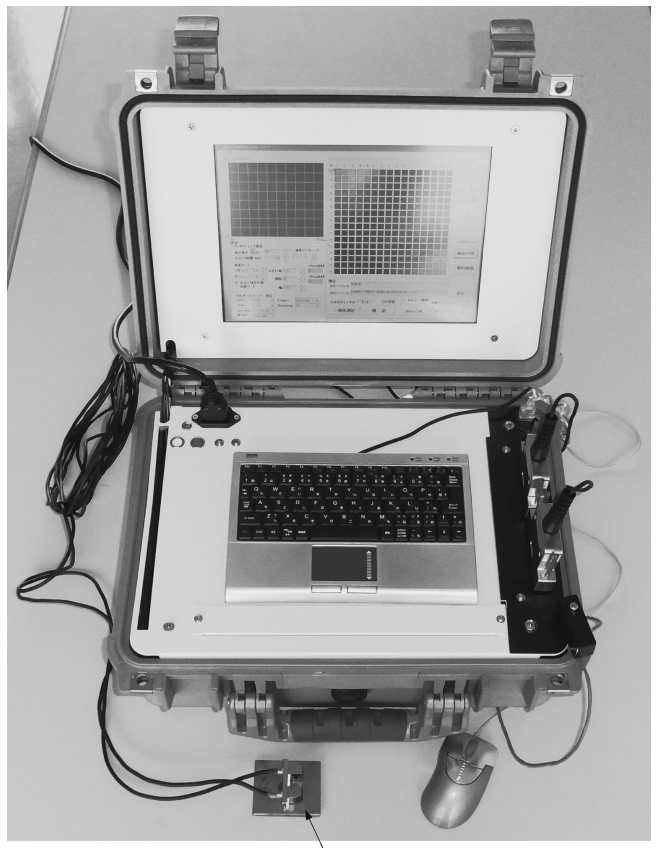

Probe array

Fig. 5 Developed measuring system.

(a) Measurement setup by using the developed probe arrays

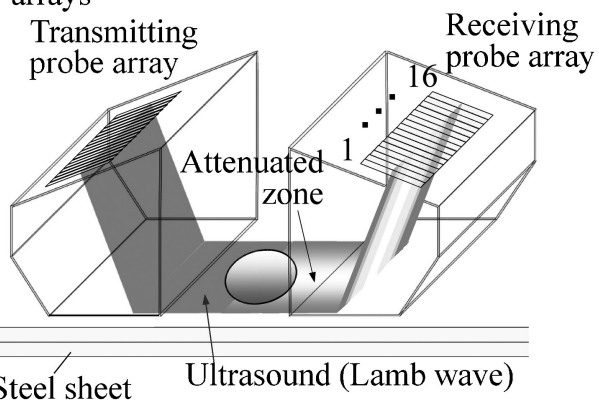

(b) Appearance of the developed probe array

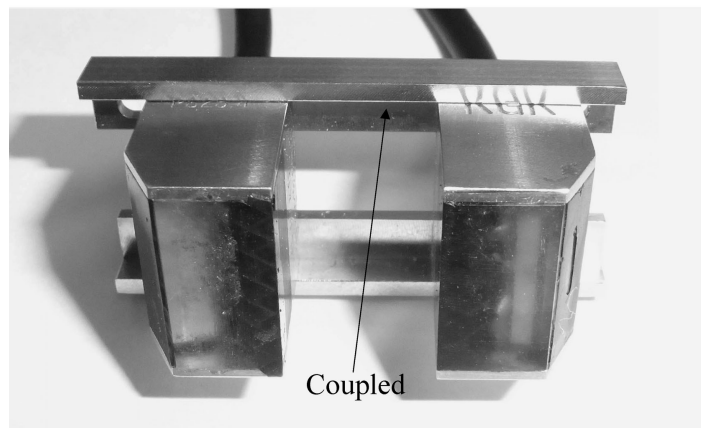

Fig. 6 Schematic depiction of (a) measurement setup by using the developed probe arrays; and (b) appearance of the developed probe arrays.
$\mathrm{MHz}$ ，アレイ配列方向素子幅 $0.5 \mathrm{~mm}$ ，アレイ配列方向素子 間隙 $0.1 \mathrm{~mm}$ の 16 圧電素子から構成されている. 広帯域パ ルスを測定に用いる理由は，透過波相互，あるいは，他の雑 エコーとの干渉を防止するためである.

この方法で用いた Lamb 波は屈折角約 $32^{\circ}$ の横波 (SV 波) と屈折角約 $78^{\circ}$ の縦波の組み合わせである。この波は partial waves ${ }^{13)}$ と称するべきかもしれない，また，Fig. 4 を参照す ると，溶接金属を通過した透過波は溶接金属を通過しない透 過波よりも遅れて受波されることが予想される.

この測定装置では，送波振動子アレイの全素子と受波振動 子アレイの全素子との間を伝搬した透過波を検出する．送波 用振動子アレイの $i$ 番目 $(i=1,2, \cdots, 16)$ の素子(送波素子と も称する) から 1 つずつ順に送波された透過波を受波用振動 子アレイの全素子 (16 素子，受波素子とも称する)によって 1 つずつ順に受波する。全部で $256(16 \times 16)$ パスに沿って透 過した透過波の振幅が検出されるようになっている。言い換 えれば，斜めパスの透過波の振幅も検出される.

スポット溶接部のナゲット径は Fig. 7 (a)に示す 31 経路に 沿って透過し受波された透過波の振幅を用いて測定される. この経路に沿って伝搬した透過波は到達時間遅れに基づいて 認識され，その振幅と伝搬時間が検出される. Fig. 7(b)に

(a) Through-transmitted wave propagating along 31 paths

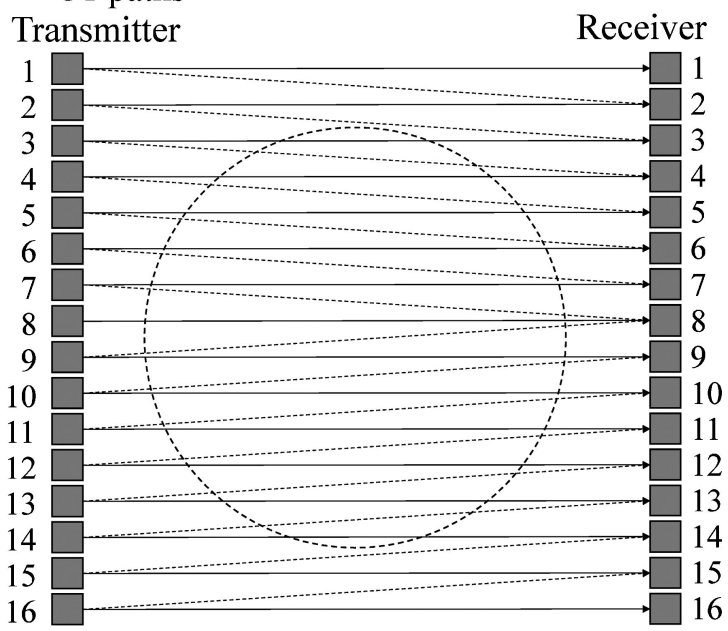

(b) Determination method by comparing wave amplitude with predetermined threshold value.

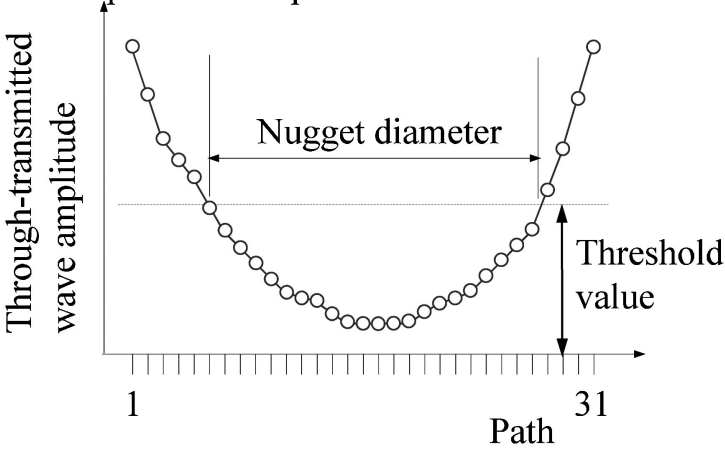

Fig. 7 Nugget diameter measurement by using (a) throughtransmitted wave propagating along 31 ultrasound paths and (b) determination method by comparing wave amplitude with predetermined threshold value. 
示すように，受波した透過波のアレイ配列方向への振幅プロ フィルは上述した受波透過波の振幅を用いた補間によって決 定される. その後, 振幅が所定のしきい值より低い部分の空 間幅がナゲット径として測定される. 透過時間の測定では, 溶接金属の外側を伝搬した透過波の伝搬時間が基準時間とし て用いられる。基準時間をもとに設定された時間遅れよりも 透過波の透過時間が長い経路が溶接金属を有すると判断され る.

さらに，すべての経路について測定された透過波振幅がマ トリックス状に表示される. 個々の表示素子の輝度は透過波 の振幅に応じて変調されており, 明るい表示は, 受波された 透過波が大きい振幅を持っていることを示す. Fig. 8 に模式 的に示すように，このマトリックス表示は振動子アレイとス ポット溶接部との位置関係を決定するのに用いることができ る. 描画の簡単化のため, 同図は振動子アレイが 8 素子 (全 部で 64 経路)の場合を描いている.ナゲット径を精度よく 測定するには，Fig. 7(a)に示す 31 の超音波伝搬経路内に溶 接金属を位置させる必要がある.マトリックス表示は振動子 アレイとスポット溶接部との位置合わせを容易に行うための

\section{Transmitting array Receiving array}
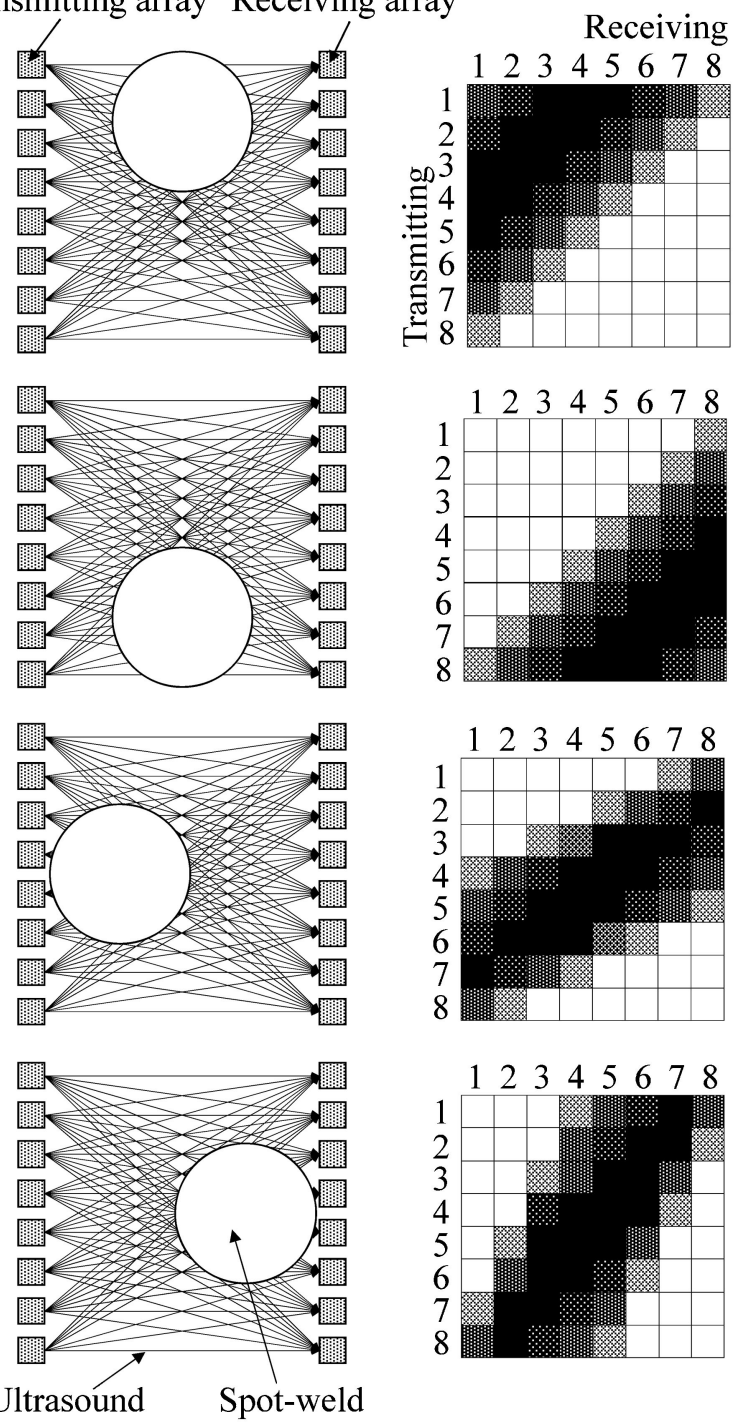

Ultrasound Spot-weld

Fig. 8 Detection of misalignment using matrix display.
測定支援機能である。

なお，マトリックス表示に抢いて右下がりの対角線に並ん だ暗い表示素子の数はナゲット径に大まかに対応するので, ナゲット径が大きいか, あるいは小さいかを直観的に示す測 定者向け補助機能として使うことが可能である.

本装置による測定時間はスポット溶接部 1 点当たり， 3 秒 未満である。

\section{2 供試材}

Table 2 に示すスポット溶接サンプルを供試材として用い た. サンプルは板厚 $0.7 \sim 2.0 \mathrm{~mm}$ の 2 枚の鋼板を重ねてス ポット溶接することにより製作された．溶接電流の加減によ ってナゲット径がいくつか変えられた. ナゲット径 $0.0 \sim 6.0$ $\mathrm{mm}$ のサンプル作成が上記方法によって可能であった.

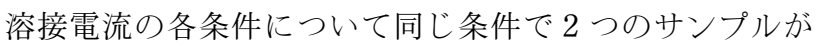
製作され, 一方(試験サンプル) は超音波測定に用いられ, 他 方(基準サンプル)はナゲット径(基準径)の測定のため切断さ れた. 測定されたナゲット径は Table 2 の一番右側の欄に示 されている. 全部で 17 セット 68 個のサンプルが準備され た.

\section{3 測定結果および考察}

サンプルは表裏面の互いに直交する 2 つ方向から測定 された.よって，サンプルあたり 4 回の測定が実施された. 3.1 に示したのと同じプローブがすべての測定に用いられた. Fig. 9 は Table 2 に示したサンプルを用いて, 水平方向減衰 測定に基づく上述した方法により測定されたナゲット径 $D_{\mathrm{M}}$ と断面観察により決められた基準径 $D_{\mathrm{R}}$ との関係を調べた結 果を示す. Fig. 9 に示すように, いくつかのサンプルを除い て, ナゲット径測定值 $D_{\mathrm{M}}$ と基準径 $D_{\mathrm{R}}$ とは $0.5 \mathrm{~mm}$ の精度 で一致した。溶接金属がないサンプルの測定で過大評価が発 生する傾向があった，過大評価の原因のうち可能性が高いと 思われるものは以下のとおりである.

（1）溶接中の高温により生成された粗大な結晶粒が超音波を 減衰させた。

（2）非破壞測定に用いたサンプルの実際のナゲット径が基準 ナゲット径とはある程度異なっていた可能性がある。なお， 非破壊測定に用いたサンプルの切断試験結果に基づく測定精 度の正確な評価は今後の課題としたい。

ところで，上述してきたように小さい溶接金属しかない， あるいは，溶接金属がないスポット溶接部は強度不足のため 有害であり，それらは確実に排除されなければならない。そ こで，ナゲット径を過大評価しないことは重要である.よっ て，著者らは減衰測定に基づくナゲット径測定方法にさらに 改良を加えた。

Fig. 10 は上述した 31 経路で受波された信号を用いて作 成された B スコープの例である. 横軸は時間であり, 縦軸 は Fig. 7(a)に示した超音波経路である.Fig. 10 に示されて いるように基準ナゲット径が 0 のサンプルでは, 中心の経 路の透過波上端の経路の透過波との時間差がきわめて短い. それは，超音波速度を変化させる溶接金属がないからであ る.これに対し, 基準ナゲット径が大きいサンプルでは, 中 
Table 2 Samples for nugget diameter measuring test.

\begin{tabular}{|c|c|c|c|c|c|c|c|c|}
\hline \multirow[b]{2}{*}{ No. } & \multicolumn{2}{|c|}{ Top side sheet } & \multicolumn{2}{|c|}{ Bottom side sheet } & \multicolumn{4}{|c|}{ Reference Nugget diameter, $D_{\mathrm{R}} / \mathrm{mm}$} \\
\hline & $\begin{array}{c}\text { Tensile strength, } \\
T S_{\mathrm{T}} / \mathrm{MPa}\end{array}$ & Thickness, $t_{\mathrm{T}} / \mathrm{mm}$ & $\begin{array}{c}\text { Tensile strength, } \\
T S_{\mathrm{B}} / \mathrm{MPa}\end{array}$ & Thickness, $t_{\mathrm{B}} / \mathrm{mm}$ & Type A & Type B & Type C & Type D \\
\hline 1 & 270 & 0.7 & 270 & 0.7 & 0.0 & 1.1 & 3.8 & 4.5 \\
\hline 2 & 270 & 1.2 & 270 & 0.7 & 0.0 & 0.0 & 2.7 & 5.4 \\
\hline 3 & 590 & 1.2 & 590 & 1.2 & 0.0 & 3.1 & 4.5 & 5.2 \\
\hline 4 & 590 & 1.6 & 590 & 1.6 & 1.0 & 3.0 & 4.6 & 5.9 \\
\hline 5 & 590 & 2.0 & 590 & 2.0 & 0.0 & 3.2 & 4.6 & 6.0 \\
\hline 6 & 980 & 1.0 & 980 & 1.0 & 0.0 & 2.9 & 4.3 & 4.8 \\
\hline 7 & 980 & 1.2 & 980 & 1.2 & 1.5 & 2.8 & 4.2 & 5.2 \\
\hline 8 & 980 & 1.6 & 980 & 1.6 & 0.0 & 2.8 & 4.3 & 5.1 \\
\hline 9 & 270 & 1.2 & 270 & 1.2 & 0.0 & 2.8 & 3.8 & 5.1 \\
\hline 10 & 440 & 1.2 & 440 & 1.2 & 0.0 & 3.0 & 4.7 & 6.0 \\
\hline 11 & 590 & 1.2 & 590 & 1.2 & 0.0 & 3.1 & 4.5 & 5.6 \\
\hline 12 & 780 & 1.2 & 780 & 1.2 & 0.0 & 2.9 & 4.2 & 4.6 \\
\hline 13 & 270 & 1.2 & 980 & 1.2 & 0.0 & 2.1 & 3.7 & 5.3 \\
\hline 14 & 440 & 1.2 & 980 & 1.2 & 0.0 & 2.7 & 4.3 & 5.0 \\
\hline 15 & 590 & 1.2 & 980 & 1.2 & 0.0 & 2.9 & 4.4 & 5.2 \\
\hline 16 & 270 & 1.2 & 270 & 1.2 & 1.5 & 2.8 & 4.5 & 5.6 \\
\hline 17 & 590 & 1.2 & 270 & 1.2 & 0.0 & 2.7 & 4.2 & 5.1 \\
\hline
\end{tabular}

$T S_{\mathrm{T}}$ : Tensile strength of top side sheet, $T S_{\mathrm{B}}$ : Tensile strength of bottom side sheet, $t_{\mathrm{T}}$ : thickness of top side sheet, $t_{\mathrm{B}}$ : thickness of bottom side sheet.

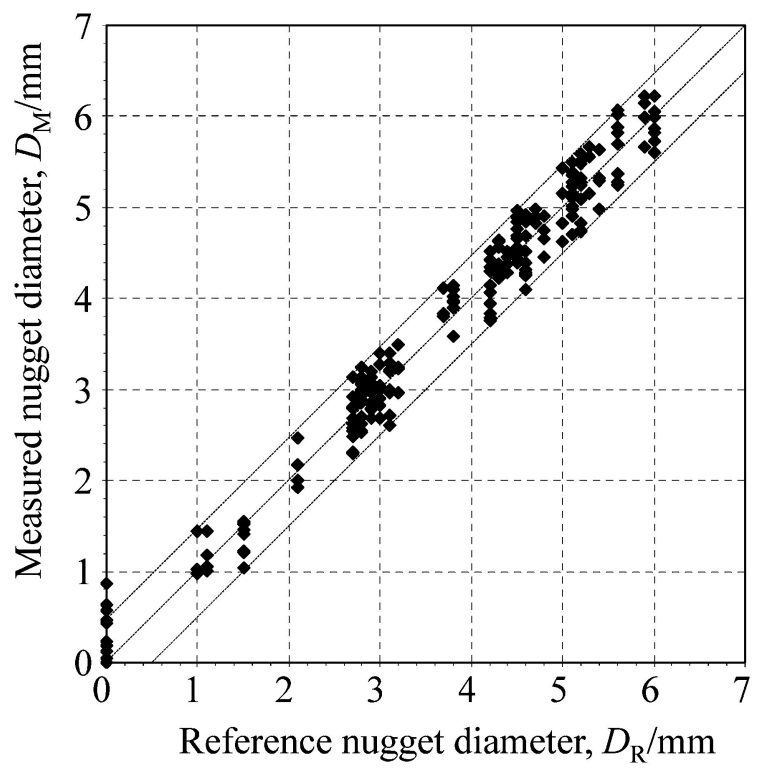

Fig. 9 Relationship between measured nugget diameter and reference nugget diameter.

心の経路の透過波と端の経路の透過波との時間差が長い。す なわち，減衰測定により測定されたナゲット径を伝搬時間測 定結果を用いて補正することが可能である．透過波の伝搬時 間が基準時間をもとに設定された時間遅れよりも短い経路は 溶接金属を含をないと判定し，ナゲット径を０と決定する ようにする.

Fig. 11 は，水平方向減衰測定に基づく上述した方法によ り測定されたナゲット径 $D_{\mathrm{M}}$ に伝搬時間に基づく補正を加え た結果と基準ナゲット径 $D_{\mathrm{R}}$ との関係を示す．開発した方法 (a) No weld metal

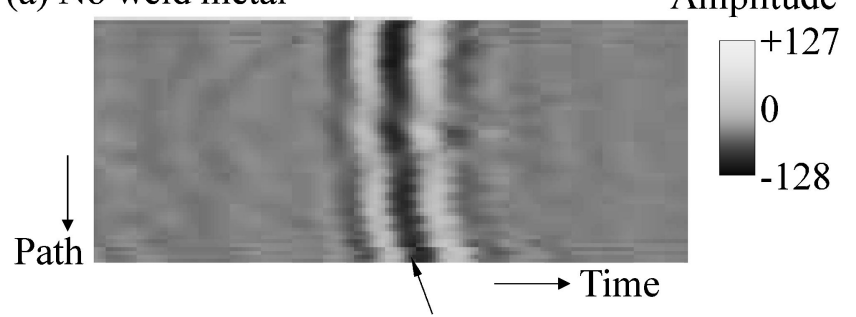

(b) Large weld metal Through-transmitted wave

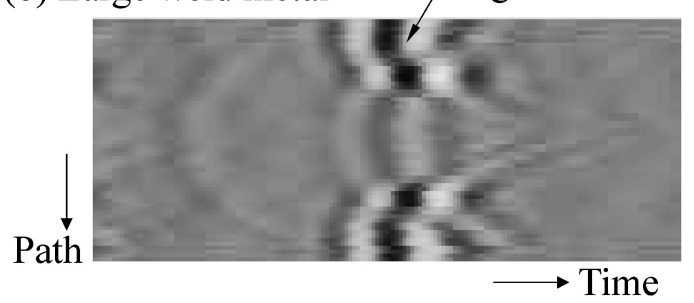

Fig. 10 Comparison of B-scope between (a) a sample with no nugget and (b) a sample with large nugget.

を用いて溶接金属がないスポット溶接部を正確に識別できる.

透過時間測定だけを用いることによりナゲット径を測定で きることも期待される．しかし，厚さ方向に指向した組織の 方向はスポット溶接の条件に依存してある程度変化する可能 性がある。そこで，溶接金属が有する異方性から生じる時間 遅れも溶接の条件に依存して変化する可能性がある. よっ て，透過波の時間遅れを所定のしきい值と比較することによ って測定されるナゲット径は十分な精度を有さないであろう。

Fig. 10 を再び参照すると，期待どおり，溶接金属を含む 経路を透過した波の透過時間は溶接金属を含まない経路を透 過した波の透過時間よりも長いことが観察された。このよう 


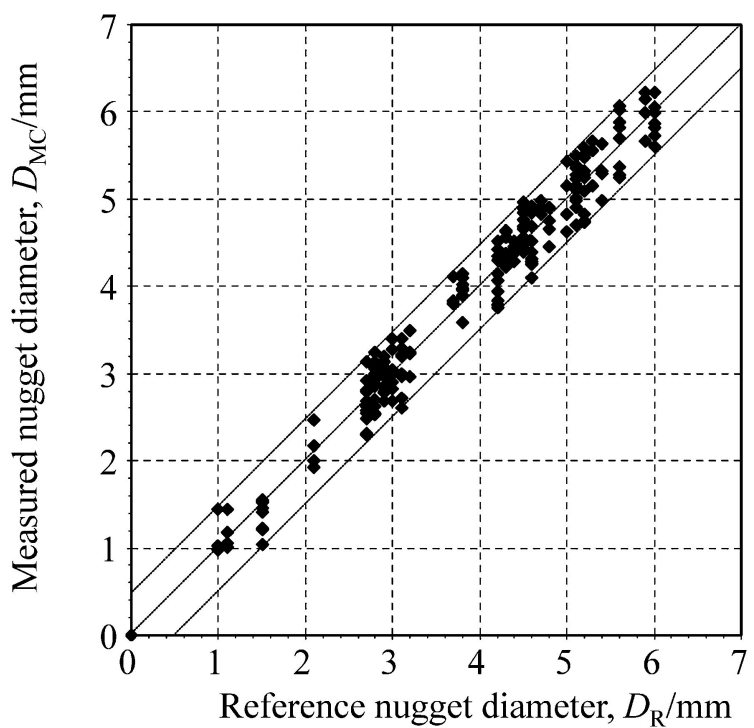

Fig. 11 Relationship between measured nugget diameter after compensation and reference nugget diameter.

に溶接金属を通過する超音波の速度は溶接金属の異方性に依 存して変化することが定性的に確認された.

実用に向けて, 対にした振動子アレイを曲面にマッチング させることが解決すべき課題と考えられる. これは今後の重 要な課題である.

\section{4. 結 論}

著者らは超音波(板波)の水平方向透過測定に基づくスポッ 卜溶接部非破壊評価方法を開発し，以下の結論を得た.

（1）透過波の大きな減衰が観察される部位の平面的な幅を 測定することによりナゲット径を評価することができる.
（2）透過波の透過時間をスポット溶接部の外側を伝搬する 透過波の基準透過時間と比較することにより，溶接金属がな いスポット溶接部を正確に識別できる.

（3）圧電振動子アレイを用いて, 透過波の大きな減衰が観 察される部位の平面的な幅を測定することにより溶接金属の 大きさ (ナゲット径)を測定し, 透過波の透過時間を用いて溶 接金属がないスポット溶接部を判別してナゲット径測定值を 補正する測定システムを開発した。このシステムによる測定 結果は断面観察により測定されたナゲット径とよく一致した.

\section{文献}

1) The Japanese Society for Non-Destructive Inspection: Ultrasonic Testing III, (The Japanese Society for NonDestructive Inspection. Tokyo, 2001) pp. 235-236 (in Japanese).

2) T. Matsushima: Proc. JSNDI Fall Conf., (Fukuoka, 2001) pp. 57-58 (in Japanese).

3) T. M. Mansour: Materials Eval. 46 (1988) 650-658.

4) S. Rabinovich, K. Jassby, O. Livni and R. Aharoni: Proc.15th World Conference on NDT, (Rome, 2000) idn 372.

5) G. Mozurkewich: Proc. 16th World Conference on NDT, (Montreal, 2004) p. 303.

6) P. Buschke and W. Schappacher: Proc. 9th European Conference on NDT, ECNDT 2006-Fr.1.6.2, (Berlin, 2006).

7) F. Reverdy and D. Hopkins: Review Progress Quantitative NDE, Vol. 23 A, (Am. Inst. Physics, New York, 2004) pp. 801-808.

8) T. Ikeda, H. Karasawa, S. Matsumoto, S. Satonaka and C. Iwamoto: IIW Doc. No. III-1343-05.

9) T. Ikeda, H. Karasawa, S. Matsumoto, H. Isobe and T. Nakamura: IIW Doc. No. III-1494-08.

10) A. A. Denisov, C. M. Shakarji, B. B. Lawford, R. Gr. Maev and J. M. Paille: J. Res. Natl. Inst. Stand. Technol. 109(2004) 233244.

11) J. L. Rose: Ultrasonic Waves in Solid Media, (Cambridge Univ. Press, Cambridge, 1999) pp. 24-33.

12) J. L. Rose: Ultrasonic Waves in Solid Media, (Cambridge Univ. Press, Cambridge, 1999) pp. 358-367.

13) J. L. Rose: Ultrasonic Waves in Solid Media, (Cambridge Univ. Press, Cambridge, 1999) pp. 107-109. 